\title{
HOW TO TEACH CAD SYSTEM?
}

\section{Vladimír SOTÁK - Martin KUNÍK - Robert SOTÁK}

\begin{abstract}
The contribution deals with selected issues from the area of teaching CAD/CAM systems, particularly AutoCAD. It consists of a part called the methodical guide book on teaching AutoCAD and the proposal for time-content plan of teaching. In the process of teaching we emphasize fundamental didactical principles, especially those of succession and visualization.
\end{abstract}

Key words: CAD, CAM, AutoCAD, computer skills, software support, programming, educational standards, teaching process.

\section{AKO VYUČOVAŤ CAD?}

Abstrakt: Príspevok je venovaný vybraným problémom výučby systémov CAD/CAM, konkrétne AutoCAD-u. Obsahuje krátku ukážku metodickej príručky pre výučbu v prostredí AutoCAD, a návrh časovo-obsahového plánu výučby. Pri výučbe zdôrazňujeme rešpektovanie základných didaktických zásad, najmä zásady postupnosti a názornosti.

Kl'účové slová: CAD, CAM, AutoCAD, počítačové zručnosti, softvérová podpora, vzdelávací štandard, vyučovací proces.

\section{Introduction}

In the contribution published in the previous JTIE copy we focused on teaching CAD/CAM systems from the point of view of concordance between theory and practice in above-mentioned area. In „Technológia vzdelávania“ magazine published by UKF in Nitra we introduced our educational standard for teaching AutoCAD. Content of this contribution is orientated on the fundamental tool - methodical guide book which we used and verified in teaching CAD/CAM systems.

\section{Conditions for teaching CAD/CAM systems}

Teaching CAD/CAM systems at secondary vocational schools orientated on engineering is being extremely underestimated nowadays. Teachers who teach CAD/CAM systems are fully aware of the bad situation. Unfortunately, often happens that those who do not master and are of no interest towards CAD/CAM systems enforce higher lesson donation for other subjects at the expense of CAD/CAM systems.

In 1999, the State Institute of Vocational Education started a project that was orientated on implementation of graphic systems into the curricula at secondary vocational schools in these branches: engineering, electro engineering, building and constructions, electro engineering in transport, operation and economics in transport road transport, general transport. Thanks to this project these CAD systems have been widespread in engineering area: AutoCAD, Mechanical Desktop and Pro/DESKTOP. A new agreement was accepted with some companies that were willing to offer school licences. For more information visit: http://www.siov.sk/siov/dokhtm/1 vzdprog/64zav grs.htm.

From that time the school licences were offered by other firms and companies and the list of them is always being extended. So far, no united philosophy of teaching CAD/CAM systems has been elaborated. Every school that offers teaching CAD/CAM systems decides independently from others, based on their own criteria and needs towards practice. That is why there are so many CAD/CAM systems being taught at schools and it is hard, almost impossible to create the united methodology.

\section{CAD/CAM systems at secondary schools}

In the second half of the 90 s of the previous century a rapid development of Slovak engineering was recorded. More progressive methods based on computer graphics were implemented into construction processes and technological preparation of production and so the era of CAD and CAM systems started. Hand in hand with this phenomenon a new demand for specialists and technicians dealing with the above mentioned technologies appeared. We talk about practically all levels of employees - from the 
specialists who attended university, technicians from secondary schools up to the apprentice centres graduates. That is why CAD/CAM systems have been implemented into the educational process at secondary schools

\subsection{Aim of the education}

The aim of education is to teach students how to master CAD/CAM systems, and truly, not at professional level as only practice itself can teach it. In the CAM part it is needed to comprehend the philosophy of mastering the software. After this, students should be ready to work even with other CAM systems. It is similar in the CAD systems. Here, the emphasis is put on how efficiently they will be used in the educational process. Regarding rapid development in the area of technologies and contemporary demands from the side of practice there are more and more perfect and complicated systems being created.

In the IT CAD magazine, copy 6/2004 (CAD/CAM systems in education at secondary vocational schools), master Miloslav Štulpa expresses his opinions on various reactions of pedagogues regarding implementation of CAD/CAM systems into schools. (2004, p.40)

From one side, the reactions are extremely positive, recorded among the teachers who are keen on the particular area and also work under suitable conditions what means they teach only one CAD/CAM system, or two that are similar in content. On the other side there is an opposite extreme where a pedagogue after first contacts refuses particular software arguing that such software is unsuitable for teaching and they require a newer version.

We identify with the author of the article. Though he writes about the situation in the Czech Republic, the situation is very similar in many other countries, including Slovakia. Based on the personal experience we dare say that pedagogues express different standpoints on teaching CAD/CAM systems. One group of teachers works seriously every day and try to teach their students maximum for the practice, the other group of teachers obviously express their disinterest; especially, by the way they teach. As a result of this students are not adequately prepared for practice in the area of both CAD and CAM systems.

Author of this article also writes about attitude of superior pedagogues. One group of them requires sudden and correct decision of a teacher based on a short presentation by a seller. They think that software is like goods in a shop, where there is a short review and good price enough to close a bargain. Another extreme shows us the danger of over-estimating teacher's skills and abilities hoping that after one tuition they are ready to teach particular subject at full-fledged level. Often we witness situation when superior teachers see that teachers can master one CAD system perfectly, and they order them to learn the principle of another one based on a different philosophy and with distinct controls. Unfortunately, they offer only minimum of time to master the new system and to elaborate the most suitable methodology.

Many schools and teachers are not able to implement new modern technologies into the educational process correctly, or in worse case not at all. In such schools CAD and CAM systems are used not as a mean, but as an aim of learning We also meet with over-estimating of $\mathrm{CAD} / \mathrm{CAM}$ systems in practice, when a fact that the model or drawing was created in CATII defeats many other parameters, like the quality of created construction or whether and how long it will take to realize designed construction in the manufacturing process.

There is always problem with just partially existing concepts of implementation of teaching CAD/CAM systems, lack of suitable textbooks and materials, in many cases also with not sufficient hardware and software. We have recorded huge differences between particular schools. Traditional and repeating problem is not very well prepared curriculum or the lack of skilled teachers. The best teachers are usually considered those who come from real practice, those who are of good knowledge of CAD system and ideally with multiyear experience in the branch. Only rarely schools invest money into the schooling of their own employees because it is inadequately expensive for them. It is much easier and cheaper to buy a full-fledged teacher who is ready to teach immediately.

Other existing problem is an extreme diversity in teaching. The practice allows healthy competition between firms, but there have been too many varied software products created recently. These types if software are usually based on the similar principle, but there are differences in variety of approaches when solving particular tasks and in different controls.

Generally, we can conclude that there are many different systems at schools, some more some less suitable from the point of view of needs of the educational process. Besides, schools are forced to look at their financial scope. 
The last but not the least seems to be the problem with the software providers and whether they are interested in offering their software products to students for symbolic prices and in providing full service as if students were their clients.

There are also obvious differences between students themselves. Some work with CAD/CAM systems only a few lessons a week while the other almost all day long practically every day. Such differences must be respected from the pedagogical point of view. We always must consider suitability of a system used in the educational process as well as demands put on a teacher in their preparation for every lesson. Just because of the abovementioned facts it is practically impossible to elaborate a detailed united methodology for all the students and schools.

Many schools actively use CAD products, especially from the AUTODESK company. Interestingly enough, another part called CAM is often being forgotten that belongs to the area of technology, still it is being underestimated and neglected. Professional connection constructor (designer) - technologist is becoming more and more common in everyday practice in many companies, particularly in the instrumental workshops, where the same worker designs in $\mathrm{CAD}$ and consequently he creates a program in CAM for processing on CNC machine. This leads us to conclusion that both systems should be used at complex level.

In the process of creating methodology we precisely followed all particular principles of educational process, above all the principles of visualization, progression, adequacy and elementariness. Regarding the methodology teachers generally expressed positively, even despite some remarks that will be analyzed in the chapter orientated on the evaluation of output interview. We tried to divide particular commands to keep the principles of progression and adequacy. Even despite our effort, after consulting with teachers after finishing our experiment we had to re-evaluate our division and to regroup particular commands per more lessons. Teachers got the methodology in a digital form together with the file of basic exercises. Those were not obligatory for teachers, it depended on themselves whether they used it or not. The above-mentioned exercises are especially for the beginning teachers, so that they may easier create their own set of exercises.
When we went through and analyzed the exercises with teachers, they were so delighted with their simplicity and preciseness that they immediately decided to apply them in the educational process. As this is not the collection of tasks, it is recommended to create and use more suitable exercises for iteration of the lesson content. Teachers also had to decide whether they would use the methodology themselves or they would print and offer it to their students. In this case we were a bit disappointed when we found out at the end of our experiment that the guidebook was offered to students at the only school of all. Truly, it was created to be used as an AutoCAD textbook for students. The methodology was finished after final interview, where teachers expressed their opinions on our proposal. We have recorded two negative comments:

- Too many commands per one lesson

- Methodology has been elaborated for the version from 2006, majority of schools uses AutoCAD 2011

As to the first comment, after consulting with the teachers from practice we decided to divide AutoCAD commands for more lessons. One sentence towards the second objection - we were looking for an optimal version of AutoCAD system, the most widespread and compatible with both older and newer versions.

Teachers generally use the Czech textbook by Fořt - Kletečka (editorship PRESS) even when it is obvious that this material does not comply with demands put on the real textbook. After going through the textbook we fully agree with such evaluation. Teachers use the textbook just as a supportive teaching material, they do not really teach according to it. Besides the abovementioned textbook teachers also use various collections of exercises and their own materials prepared by themselves. In one case a teacher appreciated material of Hungarian authors who created high quality exercises on AutoCAD, what we can absolutely agree with after seeing it.

Teachers often expect only additional exercises orientated on particular (usually newer) version of AutoCAD.

We have found out that our methodology was not accessible anywhere, but at one school, where it was at teachers and students disposal even in on-line version. 


\section{Teaching AUTOCAD}

Before we start to work with AutoCAD, let us arrange the desktop according to the picture.

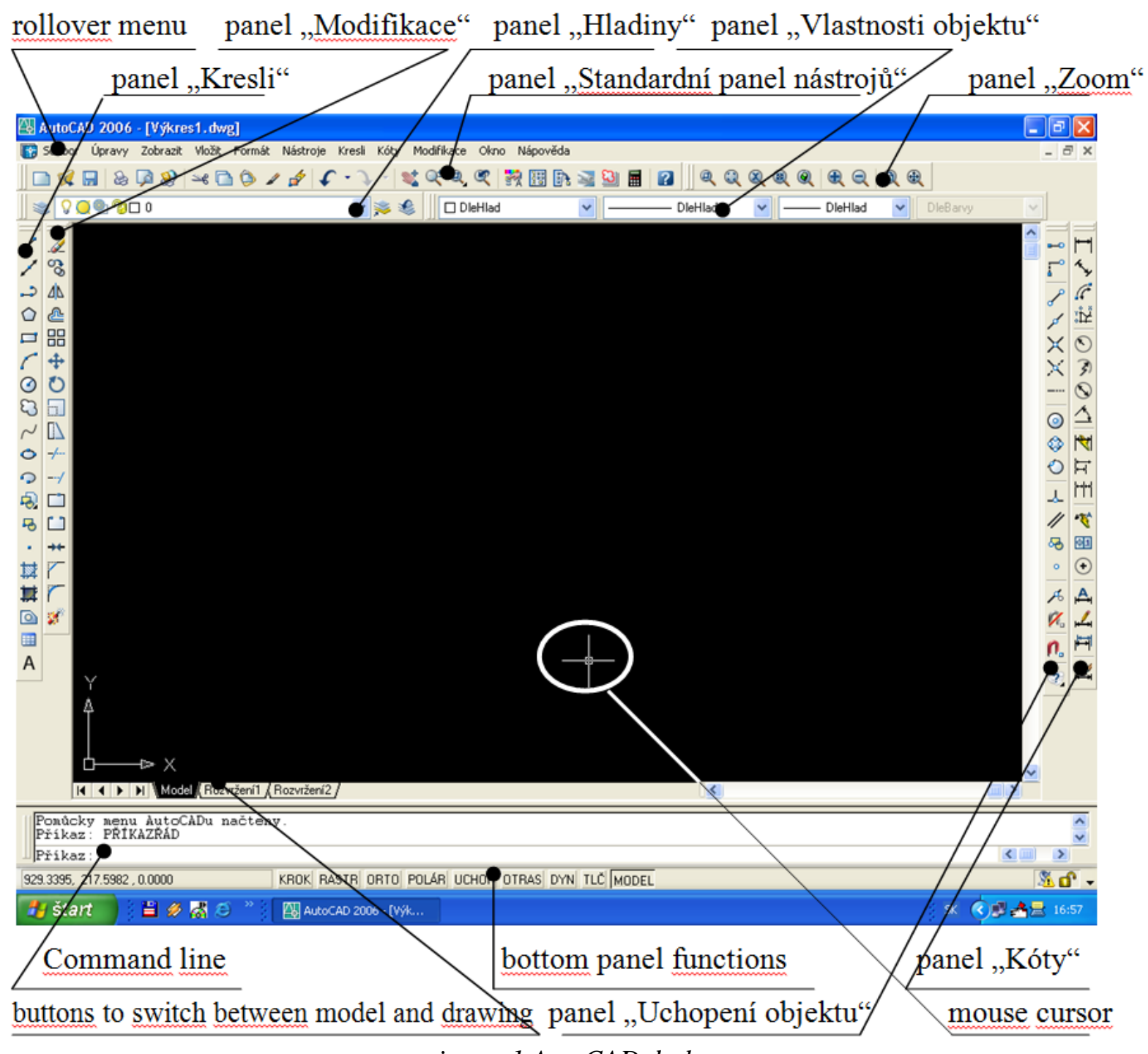

picture 1 AutoCAD desktop

We shall need following panels:

Standard control board, zoom, layers, object's attributes, draw, modification, catching the object, dimensions.

If there are any extra panels, we can hide them by moving them on the desktop what enables to close it via „, $\mathrm{x}^{\prime}$ click. All panels can be activated for moving by clicking and holding beyond the double line at the top. To activate any other so far closed panels click the right button on any command. This opens the list of all available panels. Choose only those that are missing according to the list of panels above. Now, when the work environment of AutoCAD is adjusted appropriately, we can start with teaching particular commands. We deem it important to emphasize that the AutoCAD version according to which the guidebook has been elaborated is AutoCAD 2006.

It is possible that there is an older or newer version of AutoCAD installed on your computer and that is why some commands might be executed in a bit different way. Fortunately, the basic principle of controlling the system is the same and it is quite easy to master the set of commands. When you watch the command line carefully, you always know what to do.

One part of the guidebook is the $\mathrm{CD}$ where there are tasks and exercises dealing with particular commands. In the frame of one exercise students have a chance to iterate also previously learnt commands. The most important element in AutoCAD is the rollover menu. Such menu is being used in practically all programs that work 
under operating systems known as GUI (Graphic User Interface), just like Windows.

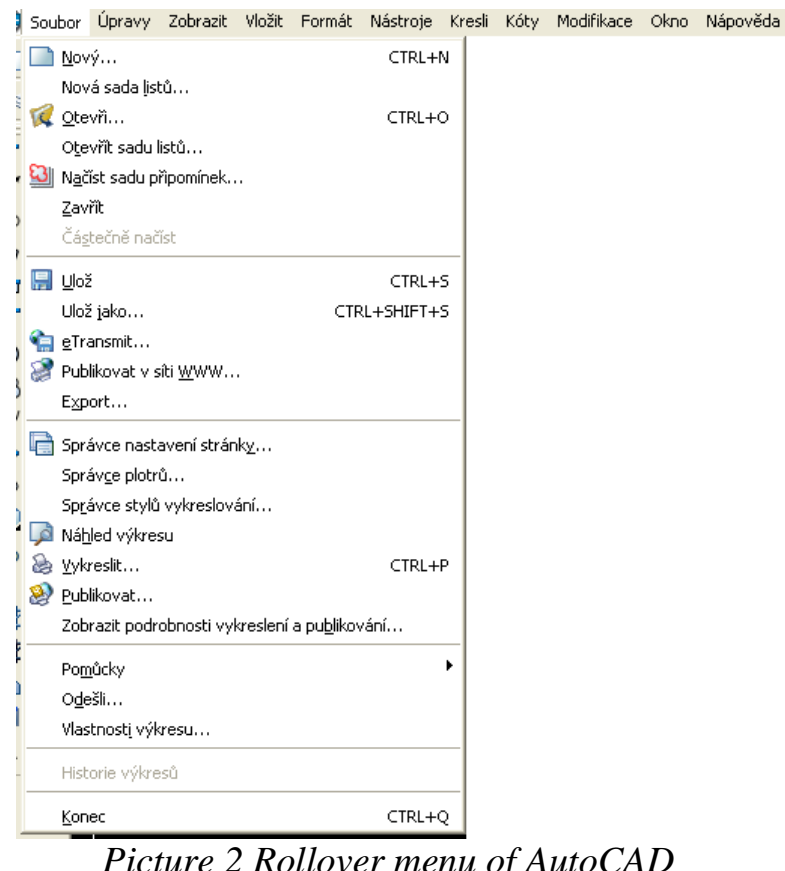

Rollover menu offers the file manager "Soubor“" with possibilities „Nový...“, „Otevři...", „Ulož“, „Ulož jako...“" a „Vykreslit...“.

Function „Nový...“ is explained in the next chapter, just briefly, it serves to open a new drawing paper with a possibility to choice particular drawing norm.

Function „Otevři..." opens saved drawing from the disc or other media.
Function „Ulož“ saves the drawing project with all changes into the drawing file under currently valid name.

Function „Uložit jako...“ has the same meaning as the previous one, and in addition it offers the choice where and under what name to save the project.

Function „Vykreslit..." serves to print the drawing on the paper in the connected printer.

There are two tool panels under the rollover menu: „Standardní panel nástrojü“, „Zoom“, „Hladiny“ a „Vlastnosti objektu“. Panels are on both sides of the main window. On the left there are: „Kresli“" and „Modifikace“ and on the right side: „Uchopování Objektu“ and „Kóty“.

The black window in the middle is called a work window where we create a drawing. It only helps us to see the model of component, if we want to see the component directly at the drawing we have to use buttons in the bottom part of the window.

\section{Model Rozwžení1/Riozvžení2}

picture 3 Buttons to switch between model and drawing

In the bottom part of a window there is a command line that can be activated not only by clicking at its icon, but also by writing into this line.

\begin{tabular}{|c|c|}
\hline $\begin{array}{l}\text { Pomúcky menu autoCADu načteny } \\
\text { Prúkaz: PRTKAZRKAD }\end{array}$ & $\hat{\hat{v}}$ \\
\hline Přikaz: & $<$ 國 \\
\hline
\end{tabular}

picture 4 Command line

The bottom panel with its functions is very important in the AutoCAD system. Their meaning will be described in further chapters.
We recommend to set the functions according to the picture 5 .

\section{KROK RASTR ORTO POLAR UCHOP OTRAS DYN TLČ MODEL picture 5Functions of the bottom panel}

\subsection{Command „Úsečka“}

Command „Úsečka“" is in the panel „Kresli“. It is the very first command in the row and we shall get familiar with it as the first one.

Usage:

After clicking at the command we first set the initial point and then by another click we set the final point of a line. Command „Úsečka“ is still active, we can continuously draw other lines. To deactivate function that enables drawing lines we must click the right mouse button and choose „Vložit", or push Enter or Space key on the keyboard.

To draw a line of exact length we need to input particular number expressed in millimetres into the command line. When drawing a line with decimal length, do always use the point, not the comma (6.85). 
In technical drawing it is important to keep the principles of rectangular coordinate system. AutoCAD has a function that enables to draw right-angled lines automatically. This function is in the bottom panel and it is called "ORTO". When activated, user can only draw lines under right angle.

\subsection{Command „Vymaž“}

Command „Vymaž" is in the panel „modifikace“ as a first one and it helps to erase any our mistakes.

Usage:

After clicking at the command, the cursor changes into a small oblong which serves to mark objects to be erased and by clicking the right button all marked object will be deleted. The command may be deactivated by clicking the right mouse button and then choosing "Vložit", or pushing Enter or Space key on the keyboard. In the end we present our proposal for teaching particular commands at school lessons. This suggestion is not obligatory, it depends on students how fast they would be able to advance. The only obligatory thing is the order of particular commands. Methodology is conceived in a way, so that it might be used as a textbook for students and thus students can learn also at home. It also may be used directly during the lesson to help students quickly find how to use particular command. Thanks to this it remains much time to assist other students who deal with more complicated problems in the process of drawing.

All commands are divided for particular lessons in a way so that they are compatible with the enclosed CD tasks from the time point of view. Directly in the lessons we recommend to use also other tasks as the enclosed $\mathrm{CD}$ is not the collection of tasks, but just a file of fundamental exercises. It is not unlikely that teaching AutoCAD can be prolonged up to double of originally planned lessons.

\section{Proposed lesson by lesson schedule for particular commands}

\begin{tabular}{|c|c|c|c|c|c|c|}
\hline 1.lesson & $\begin{array}{l}\text { Getting } \\
\text { familiar with } \\
\text { AutoCAD }\end{array}$ & Basic settings & $\begin{array}{l}\text { Command } \\
\text { „úsečka““ }\end{array}$ & $\begin{array}{l}\text { Command } \\
\text { „Vymaž“ }\end{array}$ & $\begin{array}{l}\text { Panel } \\
\text { „Hladiny“ }\end{array}$ & $\begin{array}{l}\text { Command } \\
\text { „Správce } \\
\text { vlastností } \\
\text { hladiny“، }\end{array}$ \\
\hline 2. lesson & $\begin{array}{l}\text { Command } \\
\text { „Oříznout“" } \\
\text { „Prodluž“ }\end{array}$ & Uchopovanie & Trasovanie & & & \\
\hline 3. lesson & $\begin{array}{l}\text { Command } \\
\text { „Kružnice“ }\end{array}$ & $\begin{array}{l}\text { Command } \\
\text { „Obdélnik" }\end{array}$ & $\begin{array}{l}\text { Command } \\
\text { „Polygon“ }\end{array}$ & & & \\
\hline 4. lesson & $\begin{array}{l}\text { Command } \\
\text { „Posun“" }\end{array}$ & $\begin{array}{l}\text { Command } \\
\text { „Natočit"“ }\end{array}$ & $\begin{array}{l}\text { Command } \\
\text { „Kopíruj“ }\end{array}$ & $\begin{array}{l}\text { Command } \\
\text { „Pole...“" }\end{array}$ & & \\
\hline 5. lesson & $\begin{array}{l}\text { Command } \\
\text { „Zrcadli““ }\end{array}$ & $\begin{array}{l}\text { Command } \\
\text { „Ekvid“" }\end{array}$ & & & & \\
\hline 6. lesson & $\begin{array}{l}\text { Command } \\
\text { „Zkosit"“ }\end{array}$ & $\begin{array}{l}\text { Command } \\
\text { „Zaoblit“" }\end{array}$ & & & & \\
\hline 7. lesson & $\begin{array}{l}\text { Command } \\
\text { „Rozložit“" }\end{array}$ & $\begin{array}{l}\text { Command } \\
\text { „Oblast"“ }\end{array}$ & $\begin{array}{l}\text { Command } \\
\text { „Oblouk““ }\end{array}$ & & & \\
\hline 8. lesson & $\begin{array}{l}\text { Command } \\
\text { „Elipsa““ }\end{array}$ & & & & & \\
\hline 9. lesson & $\begin{array}{l}\text { Command } \\
\text { „Spline“" }\end{array}$ & $\begin{array}{l}\text { Command } \\
\text { „Křrivka“ }\end{array}$ & $\begin{array}{l}\text { Command } \\
\text { „Šrafy..." }\end{array}$ & & & \\
\hline $\begin{array}{l}10 . \\
\text { lesson }\end{array}$ & „Odstavec...“ & Panel „Text“ & $\begin{array}{l}\text { Command } \\
\text { „Měŕítko“" }\end{array}$ & & & \\
\hline $\begin{array}{l}11 . \\
\text { lesson }\end{array}$ & $\begin{array}{l}\text { Command } \\
\text { „Tabulka...“ }\end{array}$ & & & & & \\
\hline $\begin{array}{l}12 . \\
\text { lesson }\end{array}$ & dimensions & & & & & \\
\hline
\end{tabular}




\section{Conclusion}

In this contribution we present original outcomes that may help to increase efficiency of teaching in the area of CAD/CAM systems. Our work was led by the effort to elaborate and apply methodical approach that enables students of secondary vocational schools master the basics of work with particular programs. After modification, it is possible to use this methodical approach also for many other systems.

\section{Bibliographical and webliographical sources}

BRYNYCH, M.: Jak mají 3D CAD systémy propracovanou výkresovou dokumentaci. In: IT $C A D, 4 / 2004$. s. $28-31$

BUŠ, L.: Školní software a komerční projekty?. In: IT CAD, 6/2004. s. $42-43$

FABIAN, M.: Požiadavky strojárskej praxe. CA.. gramotnost', jedna zo základných požiadaviek strojárskej praxe. In: IT CAD, 6/2002. s. $32-34$

FOR̆T, P. - KLETEČKA, J.: AutoCAD 2006. Brno: Computer Press, 2006. 432s. ISBN 802511-014-1.

HIRZ, M. - HARRICH, A. - ROSSBACHER, P.: Advanced 3D-CAD Design Methods in Education and Research [online] Publikované 25. 2. 2010. [citované 16. 4. 2011]. Dostupné z $<$ http://www.iiisci.org/journal/CV\$/sci/pdfs/GF6 80NA.pdf >

HODAS, S.: CAD I. Návody na cvičenia AutoCAD [online] Publikované 12. 5. 2005. [citované 5. 8. 2007]. Dostupné Z <http://svf.utc.sk/kgd/predmety/Cad_I.html> IBRAHIM, M.: Teaching BIM, what is missing? [online] Publikované 13. 9. 2007. [citované 16. 4. 2011]. Dostupné z
$<$ http://abudhabi.academia.edu/MagdyIbrahim/Pa pers/343073/TEACHING_BIM_WHAT_IS_MIS SING_The_challenge_of_integrating_BIM_base d_CAD_in_todays_architectural_curricula> MAREŠ, A. - SENDERSKÁ, K. - FABIAN, M. - VÁCLAV, Š.: CAD systémy $\mathrm{v}$ procesu projektování výrob a jejich implementace $\mathrm{V}$ procesu vzdělávání [online] Publikované 20. 4. 2011. [citované 16. 4. 2011]. Dostupné z <http://www.cad.cz/strojirenstvi/38strojirenstvi/2377-cad-systemy-v-procesuprojektovani-vyrob-a-jejich-implementace-vprocesu-vzdelavani.html>

ŠÍR, J.: CAD/CAM a střední školství ČR. In: IT CAD, 3/2002. s. 15

ŠTULPA, M.: CAD/CAM ve výuce na středních odborných školách. In: IT $C A D, 6 / 2004$. s. 40 41

VRŠKOVÝ, R.: CAD systém ako zdroj inovácie profilu učitel'a technickej výchovy [online] Publikované 17. 5. 2007. [citované 16. 4. 2011]. Dostupné z

$<$

http://www.pulib.sk/elpub2/FHPV/Pavelka2/pdf_ doc/vrskovy.pdf>

\section{Authors}

Doc. Ing. Vladimír Soták, CSc., Mgr. Martin Kuník, PaedDr.. Robert Soták

Katedra techniky a informačných technológií

PF UKF v Nitre

Dražovská cesta 4 Nitra

E-mail:vsotak@ukf.sk, martin.kunik@azet.sk, robert.sotak@ukf.sk 